\title{
नेपाली नारी नाटकमा प्रगतिवाद
}

\author{
कान्छी महर्जन, पिएच.डीं
}

\begin{abstract}
लेखसार
नेपालमा उत्पीडित श्रमजीवी शोषित वर्ग जुर्मुराउँदा निरड़क्रश राणाशासनको पतन भई २००७ सालमा प्रजातन्त्रको उदय भयो। तत्पश्चात् साहित्यका विविध विधामा प्रगतिवादी साहित्य लेखन आरम्भ भयो। नेपाली नाटकको क्षेत्रमा वासु पासाको किसान हो ! (२००5) पहिलो प्रगतिवादी नाटकको रूपमा देखा पर्दछ। नेपाली नाटकको आधुनिक कालखण्डमा आएर मात्र देखा परेको नारी नाट्यरचनामा पनि प्रगतिवादी चिन्तन देखिन्छ। प्रस्तुत लेखमा निगमनात्मक शोधविधिको उपयोग गरिएको छ। यसमा प्रगतिवादी चिन्तनका केही निश्चित उपकरणलाई लिएर केही प्रतिनिधि नारी नाटकमा पाइने प्रगतिवादी चेतनाको विश्लेषण गरिएको छ। यस कममा आवश्यकताअनुसार प्राथमिक र द्वितीयक स्रोतबाट सामग्री सड़लन गरिएको छ। सड़लित सामग्रीको व्याख्यात्मक र विवरणात्मक ढड़बाट व्यवस्थापन गरिएको छ। आरम्भिक चरणदेखि नेपाली नारी नाटकमा प्रगतिवाद देखिए तापनि पचासको दशकपछि प्रकाशित नारी नाटकमा प्रगतिवादको सचेत र सशक्त प्रकटीकरण देखिन्छ भन्ने नै प्रस्तुत लेखको निचोड हो।
\end{abstract}

शब्दकुज्जी : प्रगतिशील, सामन्ती तथा पूँजीवाद, श्रमशोषण, मार्क्सवादी वैचारिक चिन्तन, समतामूलक समाज।

\section{विषयपरिचय}

संसार गतिशील छ। यही गतिशीलतले गर्दा समयसंगै सामाजिक, वैज्ञानिक, सांस्कृतिक आदि सबै क्षेत्रमा परिवर्तन आयो। वैज्ञानिक आविष्कारले नयाँ नयाँ चामत्कारिक तथ्य अगाडि आइरहँदा यता वाद, सिद्धान्त र विचारमा पनि गतिशीलता देखिंदे गयो। समयसंगै नयाँ नयाँ वाद, सिद्धान्त र विचारले पुराना स्थापत्य वाद, सिद्धान्त र विचारलाई प्रतिस्थापन गर्ने कामलाई निरन्तरता दिइरह्यो । "यसैक्रममा 99 औँ शताब्दीको युरोपियन कान्तिको उपजस्वरूप स्थापित हुन आएको साहित्यिक क्षेत्रको एक विचार प्रगतिवादी विचार हो" (भट्ट, २०६९, पृ.४१)। यसको दार्शनिक तथा सैद्धान्तिक आधार भनेको दून्द्वात्मक र ऐतिहासिक भौतिकवाद हो । मार्क्स, एंगेल्स, लेनिन, स्टालिन, माओका दून्द्रात्मक भौतिकवाद र ऐतिहासिक भौतिकवादमा टेकेर प्रगतिवादी साहित्यलेखन भएको देखिन्छ। राजनीतिमा प्रयोग भएको मार्क्सवाद तथा समाजवादलाई साहित्यमा प्रगतिवाद शब्दका रूपमा प्रयोग गरेको देखिन्छ। कृष्णचन्द्रसिंह प्रधानका अनुसार "राजनीतिमा समाजवाद र साहित्यमा प्रगतिवाद एउटै कुरा हुन्" (प्रधान, २००द, भूमिका) । यसैकारण समाजवादी यथार्थवाद, माक्क्सवाद र प्रगतिवादलाई समानार्थी शब्दका रूपमा प्रयोग गरिन्छ। वर्गविहीन समाजको निर्माणलाई साहित्यको मूल हेतु बनाएर समतामूलक सुन्दर समाजको पक्षमा कलम चलाउँदा प्रगतिवादी साहित्य लेखनको आरम्भ भएको हो ।

मार्क्सवादी दर्शनलाई आधार मानेर लेखिने साहित्य अर्थात् मार्क्सवादको साहित्यिक अभिव्यक्ति नै प्रगतिवाद हो, दून्द्वात्मक तथा ऐतिहासिक भौतिकवादी चिन्तनको समिष्ट

* उपप्राध्यापक, सरस्वती बहुमुखी क्याम्पस (मानविकी सङ्काय, नेपाली विभाग), त्रिभुवन विश्वविद्यालय, नेपाल । 
नै मार्क्सवाद हो भने यसै मान्यतामा आधारित साहित्यिक चिन्तन हो प्रगतिवाद । यसले यथार्थको गतिशीलताई स्विकाई र पुनर्सिर्जन पनि गर्दछ। सामन्ती तथा पँजीवादी सामाजिक संरचना र चिन्तनको विरूद्धमा देखापरेको यस भौतिकवादी दर्शनले निम्न वर्गप्रति सहानुभाति देखाउँदै वर्गीय असमानतालाई हटाउन जोड दिन्छ । समाज व्यवस्थालाई हेर्ने यस वैज्ञानिक साहित्यिक चिन्तनले श्रम र सिर्जनालाई महत्व दिन्छ। वर्गीय संरचनायुक्त समाजमा रहेका सामाजिक, आर्थिक, राजनैतिक, सांस्कृतिक आदि सबैखाले विकृति र विसड़्गतका विरूद्ध कलासाहित्यरूपी हतियारले लडेर समातामूलक समाज निर्माण गर्न चाहन्छ, प्रगतिवाद (पोखरेल, २०६९, पृ.५ )।

प्रगतिवादी साहित्यिक अभिव्यक्तिले शोषित पीडित जनताको पक्षमा आवाज उठाएर त्यसको विरूद्धमा सझ्गठित बनेर सङ्घर्ष गर्न सबै उत्पीडितहरूलाई आह्वान गर्दछ।

नेपालमा प्रगतिवादी साहित्यिक लेखनको अवस्थालाई खोतल्दा राणाकालको उत्कर्षको राजनीतिक अवस्थासम्म पुग्नुपर्ने हुन्छ किनकि यही विन्दुबाट नेपालमा वर्ग विभेद, श्रमशोषण, अन्याय र अत्याचारको विरूद्धमा कान्तिकारी उद्घोष भएको थियो ।

प्रगतिवादी साहित्य लेखनले मार्क्सवादको राजनीतिक सिद्धान्तसंग अविभाज्य सम्बन्ध राख्दछ। नेपालमा राणाशाहीको उत्कर्षको समयसँगै कम्युनिस्ट आन्दोलन भूमिगत रूपमा प्रारम्भ भएको र राणाशाहीको उन्मूलनसँगै आफ्नो प्रभाव विस्तार र सझ्गठनात्मक प्रयास सुरु गरेको मार्क्सवादी आन्दोलनले राजनीतिसँगसँगै साहित्यमा पनि मार्क्सवादी विचार अनुसारको सरोकार बोक्ने साहित्यको सृजना होस् भन्ने चाहना राखेको र कवि र लेखकहरूको सचेत चाहनाका कारण प्रगतिशील आन्दोलन प्रारम्भ भएकोले नेपालको राजनीतिसँग यसको अविभाज्य सम्बन्ध रहेको कुरा पनि ध्यानयोग्य रहेको छ (सुवेदी, २०६९, पृ. २४६)।

२००६ सालमा स्थापित नेपाल कम्युनिष्ट पार्टीले प्रगतिवादी साहित्य लेखनका लागि बीजाधान गरेको देखिन्छ भने २००७ सालको राजनैतिक परिवर्तनपछि गठन भएका प्रगतिशील अध्ययन मण्डल, जनसाहित्य मण्डल, प्रगतिशील लेखक सङ्घ (२००९) आदिले मार्क्सवादी साहित्य सिर्जना, प्रचारप्रसार र बिक्री वितरणलाई अनकल परिवेश निर्माण गर्नुका साथै प्रगतिवादी साहित्य लेखनलाई जोड दिने काम गरयो। नेपाली साहित्यको इतिहासलाई हेरे हो भने प्राथमिककाल र माध्यमिककाल मौलिकता, भाषिकता, प्रकाशन आदिका आधारमा उपलब्धिपूर्ण रह्यो तर प्रगतिवादी साहित्य लेखनको आरम्भ आधुनिककालमा आएर मात्र भएको हो। नेपाली साहित्यमा २००६ सालदेखि प्रगतिवादी साहित्यिक लेखन आरम्भ भएको देखिन्छ । "कृष्णचन्द्रसिंहले भज्ज्याड्निरै (२००६) भन्ने कविता सड्ग्रहको भूमिकामा व्यक्त गरेका विचारलाई महत्वका साथ पढढन्छ। यसलाई प्रगतिवादी नेपाली समालोचनाको पहिलो अभिव्यक्तिका रूपमा लिइन्छ” अधिकारी, २०६९, पृ.२१०)। यसरी अधि बढेको नेपाली प्रगतिवादी साहित्यिक लेखनको यात्रामा आजसम्म थुप्रै लेखकहरू समाहित भइसकेका छन् तापनि २००६-२०१६ सम्मको अवधिलाई प्रगतिवादी साहित्य लेखनका दृष्टिले महत्वपूर्ण अवधिका रूपमा लिने गरिन्छ।

नेपाली साहित्यका सबैजसो विधाले प्रगतिवादी साहित्य चिन्तनलाई आत्मसात् गरेको अगाडि बढेको छ। नेपाली नाट्यसिर्जनामा पनि मार्क्सवादी वैचारिक चिन्तन सशक्त रूपमा व्यक्त भएको देखिन्छ। यो लेख नारी नाटककारका नाट्यसिर्जनामा मार्क्सवादी वैचारिक चिन्तन केकसरी प्रस्तुत भएका छन् ? भन्ने मूल 
समस्यामा केन्द्रित छ। यही मूल समस्यामा केन्द्रित रही समस्याको समाधानमूलक खोजअध्ययन गर्नु यसको उद्देश्य रहेको छ।

\section{अध्ययनको विधि}

२०११ सालदेखि आरम्भ भएको नारी नाट्यसिर्जनाको यात्रा हालसम्म अनेक प्रवृत्ति र मान्यताका साथ अघि बढि नै रहेको देखिन्छ। यस क्रमा नारी नाट्यसिर्जनाले प्रगतिवादी मान्यतालाई पनि अंगीकार गर्दे अगाडि बढेको अवस्था छ। त्यही अवस्थाको अध्ययन विश्लेषण गर्न यहाँ केही प्रतिनिधि नारी नाटकहरूजस्तै सावित्री पोखरेलको कलंकी समाज (२०४०), शारदा सिलवालको माटोको इज्जत (२०४३), सुधा त्रिपाठीको निःश्वासका गुजुल्टाहरू र वेदकुमारी न्यौपानेको विचलित वर्तमान (२०४६) लाई प्राथमिक स्रोत सामग्रीका रूपमा सड़लन गरिएको छ भने यी नाटक एकाड़ीका बारेमा लेखिएका लेखसमीक्षालाई द्वितीयक स्रोतका सामग्रीका रूपमा अध्ययन गरिएको छ। प्रगतिवादी मूल्य र मान्यतासम्बन्धी सैद्धान्तिक अध्ययनका लागि यससम्बन्धी पुस्तकालयीय सामग्रीको उपयोग गरिएको छ। यसरी प्राथमिक र द्वितीयक स्रोतबाट सड़लित सामग्रीलाई प्रगतिवादका निश्चित उपकरणजस्तै वर्ग सङ्घर्ष र वर्गीय उन्मुक्तिको अभिव्यज्जना, यथार्थको पहिचान र त्यसको गतिशील चरित्रको अनुसरण गर्दै समाज रूपान्तरण, आर्थिक आधारका कारण विद्यमान अन्तरविरोधको प्रतिबिम्बन, समाजमा भएका अन्याय, अत्याचार, छुवाछुत आदिको अन्त्यका निमित्त सड्गठित भएर कान्ति गर्नु, नारीलाई भोगविलासको साधन ठान्ने सामन्ती सोचको विरोधका आधारमा विश्लेषणपश्चात् विविध शीर्षक र उपशीर्षकमा व्यवस्थापन गर्दे लेखलाई अन्तिम रूप दिइएको छ।

\section{नारी नाट्यसिर्जना}

नेपाली नाट्यपरम्पराको आधुनिकाकालमा आएर मात्र नारी नाट्यसिर्जना भएका देखिन्छन् । नेपाली नाट्यपरम्परामा नारी नाट्यसिर्जनाको आरम्भलाई खोतल्दा सन् १९९४ अर्थात् वि.स.२०११ सालसम्म पुग्नुपर्ने हुन्छ। राधिका राया मलाया (सिड्गापुर)मा शिक्षिकाको पदभार लिई प्रवासकालीन समयमा बस्दा कथा, कविताका साथसाथै नाट्यसिर्जना पनि गरेको पाइन्छ। दार्जिलिडबाट प्रकाशित हुने स्तरीय मासिक पत्रिका भारतीमा सन् १९ू४ मा आदर्श दीप र जीवनको इच्छा (भारती वर्ष $७$, अड्क ७ र १०) मा कमश: प्रकाशित भएका हुन् (अधिकारी, २०४९)। सिड्गापुरस्थित सैनिक आकाशवाणीमा समय समयमा प्रसारण हुने रेडियो रूपक तथा एकाङ्की नाटक प्रतियोगितामा सन् $99 \% \gamma$ मा जीवनको इच्छाले प्रथम स्थान प्राप्त गरेको थियो। यसरी नाटककार राधिका रायाको जीवनको इच्छा एकाड्कीबाट नारी नाट्यसिर्जना आरम्भ भएको देखिन्छ। उनको २०४९ सालमा प्रकाशित जीवनको इच्छा नामक एकाड्की संग्रहमा जीवनको इच्छा, प्रेमको प्रतीक, प्रतिशोध, अधुरो कहानी, मुरली, म फर्केर आएँ, आदर्श प्रेम र मैले भूल गरैजस्ता एकाङकी संग्रहीत देखिन्छन् । तत्पश्चात् एकाङ्की जगत्मा नारी नाट्यलेखनको अवस्था शून्यबाट एक भएको हो। मायादेवी सुब्बाको पागल! पागल! शीर्षकको एकाड्की २०१४ सालको पालुवा हस्तलिखित पत्रिकामा प्रकाशित भएको पाइन्छ भने यसपछि रत्न, दिव्यात्मा, हिड्को टालोजस्ता एकाड़कीहरू विविध पत्रिकामा प्रकाशित हुन्छन् । २०१६ सालदेखि नाट्यरचनामा लागेकी शान्ता श्रेष्ठको रेडियोबाट विविध समयमा प्रसारित एकाङ्कीहरूको संग्रह दिन होइन साँकपछिको रात (२०४६) सालमा प्रकाशित देखिन्छ। एकाड्कीका क्षेत्रमा सशक्त कलम चलाउने अन्य नारी नाटककारका रूपमा कमला न्यौपाने, विद्यादेवी दीक्षित, बेज्जु शर्मा, मज्जु काँचुली, सुधा त्रिपाठी, जयन्ती स्पन्दन र विजया स्मृति आदि देखिन्छन् । 
नेपाली नाट्यपरम्परामा नारी नाटककारको पर्णाङ्की नाट्यसिर्जनाको प्रकाशन वि.स.२०१५ सालमा भएको हो । उन्नयन प्रकाशनबाट प्रकाशित श्रीमती सावित्री पोखरेल (उपाध्याय)को कलंकी समाजको दोस्रो संस्करण २०४० सालमा प्रकाशित देखिन्छ। यसको प्रकाशकीयमा लेखिएको छ : "यो नेपाली भाषाका नारी लेखिका मध्येको पहिलो प्रकाशित नाट्यकति हो। यसकारण यसलाई दोहोरयाएर प्रकाशन गर्दा पनि उन्नयन गौरव अनुभव गर्दछ,। यसपछि, २०२४ सालमा विद्यादेवी दीक्षितको हजुर बजैको तीजको दर नामक नाटक प्रकाशित देखिन्छ। नेपाली नाट्य परम्परा माधुरी भट्टराईको मूकवेदना (२०३६) रामायणमा उति महत्व नदिइएकी उर्मिला पात्रको क्रियाकलापलाई विषयवस्तु बनाएर प्रस्तुत गरिएको नाट्यकृति हो । यसपछि भारती खरेलको भाइटीका (२०४९), भद्रकुमारी घलेको गीति नृत्य नाटिका (२०४१), बाबा बस्नेतको योद्धा (२०४३), वेदकमारी न्यौपानेको एउटा कथाको अन्त्य (२०४३) र विचलित वर्तमान ( २०५६), शारदा सुब्बाको अघोषित नीलो पीडा (२०४५ र र यशोधरा (२०६५), शिवानीसिंह थारुको भर्चुअल रियालिटी : परोक्ष यर्थाथता (२०६४), हरिमाया भेटवालको आहाल (२०६९), ललिता दोषीको ख्यालख्याल ( २०७०) आदि प्रकाशित देखिन्छन् । यसरी नेपाली नाट्यपरम्परामा नारी नाट्यसिर्जना गुणात्मक र सड्ख्यात्मक दुवै रूपमा बढ़दो अवस्थामा देखिन्छ।

\section{नारी नाटकमा प्रगतिवाद}

नेपाली नाट्यक्षेत्रमा प्रगतिवादी नाट्यरचनाको आरम्भ २००६ सालबाट भएको देखिन्छ। "२००६ सालमा प्रकाशित वासु पासाको किसान हो ! नाटक नै पहिलो प्रगतिवादी नाटक हो। यो नाटक २००७ सालको कान्तिले राणाहरुलाई सत्ताज्युत गर्न सके पनि समाजमा भएको सामन्ती व्यवस्थाको अन्त्य भने सकेन भन्ने विषयवस्तुमा लेखिएको छ " (पोखरेल, २०६९, पृ. २६१)। यसपश्चात् मार्क्सवादी चिन्तनबाट अभिप्रेरित हुँदै थुप्रै नाटककारहरूजस्तै हृदयचन्द्रसिंह प्रधान, मोदनाथ प्रश्रित, रमेश विकल, विजय मल्ल, बुद्धिबहादुर थकाली, रामप्रसाद प्रदीप, बुँद राना, रायन, दिल साहनी आदिलगायतले सशक्त प्रगतिवादी नाट्यरचना गरेका देखिन्छन् । २०११ सालदेखि आरम्भ भएको नारी नाट्यरचनामा पनि मार्क्सवादी चिन्तन प्रस्तुत भएका देखिन्छ् ।

\section{वर्ग सड्घर्ष र वर्गीय उन्मुक्तिको अभिव्यज्जना}

समाज वर्गमा विभक्त भएपछि वर्गीय स्वार्थअनुरूप वर्गहरूका बिचमा दून्द्र हुनु स्वाभाविक नै हो । समाजमा वर्ग पहिचान गर्ने मुख्य आधार नै अर्थ हो। यही आर्थिक आधारमा टेकेर समाजमा वर्गको पहिचान गरिन्छ। नेपाली समाजमा वर्गीय दून्दू अद्यपि छ। "हरेक मार्क्सवादी साहित्यकारले समाजमा विद्यमान वर्गीय अन्तरविरोध र वर्ग सड्घर्षका प्रक्रियासँग अभिन्न हुँदै सर्वहारा वर्गलाई भावात्मक रूपान्तरणतर्फ उत्प्रेरित गर्नु हो" (पौडेल, २०६९, प्.९)। प्रगतिवादी साहित्यले सर्वहारा वर्गका समस्यासंग परिचित हुँदै त्यसको समाधानका निम्ति सचेत तुल्याउने काम गर्दछ।

नाटककार शारदा सिलवालको माटोको इज्जत (२०५३) एक देशप्रेमको भावले ओतप्रोत नाटक हो। यसमा माटोको इज्जतका लागि नेपाली आमाको छोरो वसन्तले प्राण उत्सर्ग गरेको कथावस्तु रहेको छ। वसन्त राणाखानदानको छोरो हो तापनि यस नाटकमा उनलाई सामन्तीका रूपमा नभई एक प्रगतिशील चिन्तन भएको पात्रको रूपमा उभ्याइएको छ। उनी समाजमा रहेको वर्गीय उन्मुक्तिका लागि धनी वर्गले अरूलाई देखाउनकै लागि गर्ने ठूल्ठूला रमभम रोक्नुपर्ने विचार राख्छन्। उनी भन्छन् : "यही धारणाले त हामी र हाम्रो देशमा गरीब र धनीका बीचमा यत्रो खाडल सृजना भएको छ नि ! हाम्रो देखासिकीले कति 
गरीबहरूलाई आफ़ना सन्तानको बिहे गर्न मार परेको होला" (पू.३४)। यदि सबै धनी वर्गले वसन्तभै सोच्न र व्यवहार गर्न थाले वर्ग सड़घर्ष हुने नै थिएन कि ? तर यो आजको पँजीवादी व्यवस्थामा सम्भव हुने कुरा होइन । पूँजीपति वर्गले गरीब तथा श्रमिक वर्गको हकहितको बारेमा विचार नगर्दाले नै वर्गीय दून्दू आरम्भ भएको हो। श्रमिक वर्गको श्रमशोषण गर्ने सामन्ती सोच पूँजीपति वर्गमा हाबी हुँदा वर्ग सड्घर्षले कान्तिको रूप लिएको हो ।

नाटककार वेदकमारी न्यौपानेको विचलित वर्तमान (२०४६) नाटकमा नेपाली ग्रामीण समाजमा विद्यमान वर्गीय दून्दूको अवस्थाको विद्रोत्मक चित्रण पाइन्छ। प्रस्तुत नाटकको अड़क तीनमा यस अवस्थाको चित्रण देखिन्छ। गणेश एक पूँजीपति सामन्ती हुन् भने यस नाटकमा उनका ऋणीका रूपमा मङ्गले रहेका छन् । यी दुईबिच वर्गीय दून्दू छ। मड़गले भन्छन् : "म गरीबलाई दया गर्नोस् हजुर ! मलाई यसरी सकुम्बासी नबनाउँनोस् । म यो गाउँ छाडेर यो उमेरमा कहाँ जाउँ ? म हजुरको पाइपाइ हिसाब गरेर तिर्ने छु ... अहिलेलाई जनी गर्नोस्। (खुट्टा समातेर रून्छ)" (प. ९३)। यहाँ गरीब वर्गले जहिले पनि पँजीपति वा धनी वर्गको गोडा समात्नुपर्ने नेपाली समाजको वर्गीय विभेदयुक्त यथार्थको चित्रण छ। सामन्ती वर्गमा धनको अह्मता हुँदा उनीहरूले मानवीयताको न्यूनतम धर्म पनि निर्वाह गर्न भुल्दछन्। मड्गलेलाई उत्तर दिँदै गणेश भन्छन् : "तेरो आँसुले मेरो पैसाको साउँ-ब्याज तिरिन्न, खोइ छोड़.... यो स्वाङ नपार.." (पृ.९३) । यहाँ सामन्ती गणेश मड्गलेजस्ता गरीबको अज्ञानताको फाइदा उठाउन समेत पछि परेका छैनन् । उनी दिएको ऋणभन्दा धेरै गुणा बढ़ी रकम मड्गलेसँग असुल्न लागिपरेका छन् । उनले मड़गलेलाई मात्र चार हजार दिएका हुन्छन् र ब्याज आदि जोड़दा आठ हजार भएको हुन्छ तर उनले मड्गलेसँग चालीस हजार हिसाब देखाएर उसको सबै धनसम्पत्तिमाथि आँखा लगाएका हुन्छन् । यो कुरा थाहा पाएका मड्गलेका छोराले गणेशलाई पिटेका छन् । हरेक मुड्कीको पिटाइसँगै गणेशले मड़गलेलाई दिएको रकम घटाउँदै अन्त्यमा वास्तविक रकमको माग गरेको छ। यसरी यहाँ मड्गलेका छोराहरू शम्भु, हरिले सामन्ती गणेशको आर्थिक अन्याय र शोषणको विरूद्धमा बाह्य दून्दू समेत गरेका छन् । उनीहरूबिच विवाद हुँदै गर्दा “त्यहाँ मुखमा आधा छोपिने गरी रूमाल बाँधेका दुई-तीन जना मान्छे एकैचोटि ग्वारगवार आउँछन् र गणेशको खल्तीबाट तमसुक किकेर च्यातच्युत पारेर फाल्दे हरि र शम्भुलाई तानेर लैजान्छन्" (पृ.९६) । जाली तमसुक बनाएर गणेश सामन्तीले मड्गलेसँग बढी ऋण असुल्न खोजेको हुन्छ। यहाँ त्यही तमसुकलाई च्यातच्युत पार्ने काम भएको छ। तमसुक च्यातिदिने कार्य शोषणविरूद्धको सशक्त विद्रोहात्मक कान्तिकारी कार्य हो। यहाँ अज्ञात समूहद्वारा त्यो काम भएको छ। यस कार्यले लागदछ कि गणेश सामन्तीको हार भयो तर पूँजीवादी व्यवस्थामा गणेशजस्ता पूँजीपतिले अनेकौ जालभेल गरेर अन्तोत्वगत्व जित आफ्नो हातमा पाई नै। "साँच्चै ! ती मङ्गलेका छोराहरू त्यो गणेशसित कगडा गरेका दिनदेखि त बेपत्तै पो भए त ! कसले कहाँ पुर्यायो होला हगि" (पृ.१०६) ? पूँजीपति वर्ग आफ्नो अहम्तालाई बचाउनका लागि जस्तोसुकै कदम चाल्न पनि पछि पर्देनन् । जसरी भए पनि तिनीहरू गरीब बर्गलाई आफ्नो दास बनाउन खोज्छन् । यहाँ मङ्गलेका छोराहरू गणेश साहूसंग कगडा भएको दिनदेखि बेपत्ता भएको र त्यसमा उनको ठूलो हात हुन सक्ने कुराप्रति सड़ेत गरिएको छ। पूँजीवादी व्यवस्थामा श्रमको शोषण हुने हुँदा मड्गलेजस्ता पात्रले जतिनै दु:ख गरेर पसिना बगाए तापनि उनीहरूको जीवनस्तर माथि उठ्न सकेको देखिंदैन ।

\section{यथार्थको पहिचान र त्यसको गतिशील चरित्रको अनुसरण गर्दै समाज रूपान्तरण}

नेपाली नारी नाटकमा तत्कालीन ग्रामीण समाजको यथार्थ चित्रण मात्र गरिएका छैनन्, नेपाली समाजमा विद्यमान कुरीति र कुपरम्पराको विरोध गर्दै प्रगतिशील समाजको परिकल्पना समेत कोरिएको पाइन्छ। 
नाटककार वेदकमारी न्यौपानेको विचलित वर्तमान (२०४६) नाटकमा मुख्यतः विश्वनाथ र पण्डित दुई पात्रमा प्रगतिशील विचारधार देखिन्छ यद्यपि यहाँ तीर्थ, सुरेशजस्ता यथास्थितिवादी पात्र पनि देखिन्छन् । ७०-७४ वर्षीय वृद्ध पात्र विश्वनाथ पुराना पुस्ताका भए तापनि उनको चरित्र गतिशील देखिन्छ। उनी राजनीतिक रूपमा पनि सचेत छन् । एकातिर उनले सामाजिक परम्पराअनुसार आफ्नी नातिनी ज्योतिको टीकाटालो कार्यक्रम गराएका छन् भने अर्कातिर समाजको विरोधको बाबजुद २१-२२ वर्षको उमेरमा विधवा बनेकी आफ़नी बुहारी ज्ञानुको पुनर्विवाह गराइदिन्छन् । यस विषयमा समाजका गणेशजस्ता यथास्थितिवादीहरू भन्छन् : "जेसुकै भन्नोस्..., लोग्ने मरेकी आइमाईले यस्तो गर्न हुँदैन"...(पृ.१२५) तर समाज रूपान्तरणमा लागेका विश्वनाथजस्ता पात्र भन्छन् : "किन हुँदैन ? मरेको त उसको लोग्ने पो हो, मन त मरेको हैन नि ! फेरि मेटिएको त उसको सिन्दूर न हो, जीवन नै मेटिएको त छैन नि“ (पृ.१२४) ! विश्वनाथले विधवा बुहारीको राजीखुसीमा पुनर्विवाह गराइदिएर गतिशील सामाजिक रूपान्तरण अभ्यासको आरम्भ गरेका छन् ।

\section{आर्थिक आधारका कारण विद्यमान अन्तरविरोधको प्रतिबिम्बन}

आर्थिक आधारका कारण समाजमा विद्यमान वर्गीय अन्तर्विरोधको प्रतिबिम्बन विचलित वर्तमान (२०४६) नाटकमा देखिन्छ। यसमा सामाजिक रूपमा मात्र होइन राजनीतिक क्षेत्रमा पनि वर्गीय विभेद अन्तर्विरोध विद्यमान चित्रण चित्रित देखिन्छ । यसलाई पूँजीवादी शासनव्यवस्थाको एक चरित्र नै मानिन्छ । यहाँ विश्वनाथ भन्छन् :

हो सन्ते ! तैले ठीकै भानिस् ! भोट हाल्ने भनेको गरीबका लागि, सामान्य जनताका लागि नयाँ भोटो हाल्ने हो ... नून-तेल खाने हो..., टुकि बत्तीमा मट्टीतेल थप्ने हो ..दुईचार छाक पेटभरि खाने हो...! धनिका लागि, नेताका लागि त खोइ के को हो ? सुट लगाएर मोटर चढ़ने हो कि ...मासु र वियर खाएर मस्ती गर्ने हो कि ...देश-विदेश घुम्ने हो कि के के हो ...(पृ. ४१) ?

कम्युनिष्ट पार्टीको घोषणापत्र समाजवादी व्यवस्थातिर उन्मूख देखिन्छ तर व्यवहारमा कम्युनिष्ट शासन व्यवस्थामा पनि माथि उल्लेख गरेकैँ अन्तर्विरोधको अवस्था देखिन्छ। गरीब जनता सामान्य जीवनयापनको सुनिश्चितताका लागि भोट हाल्छन्। उनीहरूको आवश्यकता मात्र दुईचार छाक पेटभरि खानु मात्र हो तर धनीका लागि, नेताका लागि चुनाव विलासीयुक्त जीवन र अकुत सम्पत्ति कमाउने सुवर्ण अवसर बन्न जान्छ। धनी र गरीब वर्गको इच्छा, चाहना र जीवनस्तरमा रहेको अन्तर्विरोधको प्रतिबिम्बिन यस नाटकको उद्धृत अनुच्छेदमा देखिन्छ।

\section{समाजमा भएका अन्याय, अन्याय, अत्याचार, छुवाछुत आदिको अन्त्यका निमित्त सड्ग्गठित भएर कान्ति गर्नु}

नाटककार सावित्री पोखरेल (उपाध्याय) को कलंकी समाज (२०४०) नाटकको अघिल्लो खण्डमा नेपाली सामाजिक परम्पराको यथार्थ चित्रण गरिएको छ भने पछिल्लो खण्डमा भने गतिशील समाज रूपान्तरणका सन्दर्भलाई प्रस्तुत गरिएको छ। सानैमा बालविवाह गरेकी शशी केही समयपछि विधवा बन्छिन् । उनी सामाजिक परम्पराअनुसार वैधव्य जीवनयापन गर्दछिन् र त्यसैलाई आफ्नो जीवनको नियति मान्दिछन् । प्रस्तुत नाटकमा गतिशील चरित्रका रूपमा जीवन देखिन्छन् । उनी शशीको धारणामा परिवतर्न ल्याउन 
सफल हुन्छन् । "मेरो सतीत्वमा आगो सल्काउने कोशिश नगर। छोड म जान्छु" (पृ. प२) भन्ने शशीले अन्त्यमा जीवनको प्रेमलाई स्वीकार गरी उनीसँग विवाह गरेकी छिन् । सानैदेखि महिलालाई विविध परम्पराको घेरामा बस्तुपर्ने सिकाइ अभिभावद्वारा दिइने हुँदा सितिमिति त्यसलाई नाघ्न महिलाहरू अगि सर्ने हिम्मत गर्न सक्दैनन् । यहाँ शशीले जीवनको साथ पाएर त्यसलाई नाघ्ने हिम्मत गरेकी छिन् तर त्यसलाई उनकै सासूले स्वीकार गरेकी छैनन् । उनले पकाएको र छोएको खानेकुरा खाएकी छैनन् भने छोरो जीवनलाई समेत “थुक्क जोइटिंग्रे, लाज सर्म सबै पचाएर उँधै गति उँधै मति जात न पातको भइस" प.. द६) भन्छन् । आधुनिक तथा प्रगतिशील सोच राख्ने जीवन "क्या हो जात भनेको ? स्त्री पुरुष केवल दुई जात..."(प. प९ ) भन्दै जातीय भेदभाव विरूद्ध बोल्छन् । उनी लैड़िक समानताका पक्षमा पनि बोल्छन् । जीवनले बहिनी जुनीलाई पढाउने कुरा गर्दा यथास्थितिवादी उनकी आमा मुखिनी "मेरो जिउ छउन्जेल त कहाँ छोरीलाई स्कुल स्कुल नचाएर बेश्या पार्न दिन्छु र" (पृ. ३६) ! भन्छिन् तर जीवन "कति आइमाई शिक्षक, डाक्टर, अफिसर र वैज्ञानिकसमेत छन् । आइमाई मानिस होइनन्" प. ३६) ? भन्दै प्रगतिशील विचार व्यक्त गर्दछन् । वास्तवमा समाज रहेका यिनै जीवनजस्ता प्रगतिशील चरित्रको सत्प्रयासले नै छुवाछुत, जातीय भेदभाव र कुप्रथाको अन्त्य हुँदै सामाजिक रूपान्तरण हुन सम्भव भएको हो ।

\section{नारीहरूलाई भोगविलासको साधन ठान्ने सामन्ती सोचको विरोध}

नेपाली समाज वर्गीय विभेदयुक्त मात्र नभई लैड़िक विभेदयुक्त पनि देखिन्छ। लैड़िक विभेदयुक्त सामन्ती सोचको कारणले गर्दा नेपाली समाजमा महिलामाथि विविध प्रकारका लैड़िक हिंसा हुनुका साथै अनेकौ प्रकारका बन्देजहरू सिर्जना गरिएका छन्। परम्परावादी सोचले नारीलाई केवल भोगविलासको साधन मात्र ठानेको छ तर प्रगतिवादी नाट्यसिर्जनामा नेपाली समाजमा विद्यमान यस्ता सामन्ती सोचको यथार्थ विद्रोहात्मक रूपमा उद्घाटन गरिएको पाइन्छ।

नाटककार सुधा त्रिपाठीको निःश्वासका गुजुल्टाहरू (२०५६) एकाड़ी संग्रहमा सड़लित एकाड़ीहरूमा नारीलाई भोगविलासको साधन ठान्ने सामन्ती सोचको विरोध कान्तिकारी रूपमा गरिएको छ । "निःश्वासका गुजुल्टाहरूलाई जीवन सम्कन विवश मेरी आमा र उनको जातलाई..." एकाड़ी संग्रहको आरम्भमा दिइएको नाटककार सुधा त्रिपाठीको प्रस्तुत कथनबाट नाटककारले प्रस्तुत एकाड़ी संग्रह शोषित, पीडित आमाको जात अर्थात् नारी जातलाई समर्पण गर्दै तिनका निःश्वास गुजुल्टाहरूलाई श्वास दिन खोजेको प्रष्टिन्छ ।

उनी फर्कदिनन् कि! एकाड़ीमा अमृत आज पश्चात्तापमा छन् । उनले आफ्नी श्रीमती बिन्दुलाई केवल एक भोग्याका रूपमा मात्र हेरे र व्यवहार गरे । अमृतको परम्परागत पुरुषवादी सोचले पढेलेखेकी शिक्षित बिन्दुको घरबाहिरको सक्रिय गतिविधिलाई सहर्ष स्वीकार्न गर्न सकेन। यहाँ बिन्दुले अन्तर्राष्ट्रिय नारी दिवसमा नारी स्वतन्त्रतासम्बन्धी गरेको भाषणलाई अमृत लज्जास्पद विषय मान्छन् । उनी भन्छन् : "नारी स्वतन्त्रता चाहियो रे, कुन्नि केरे केरे ! के खोज्या तिमीले ? आफू त भाँडियौ भाँडियौँ, संसारका छोरीबेटी पानि बिगार्न थाल्यौ ? चाहिंदैन ? चाहिंदैन मलाई तिम्रो राजनीति" (पृ.६)। यहाँ बिन्दुले आफ्नो स्वतन्त्रता र अस्तित्वको बारेमा बोल्दा अमृतको विचारमा राजनीति बनेको छ। अमृतको यस भनाइबाट बिन्दुको आत्मस्वाभिमानको चोट पुग्छछ। उनी आफ्नो पति अमृतको परम्परावादी सोचको विद्रोहात्मक प्रतिकार गर्दे भन्छिन् :

तिमी सहन सक्तैनौँ भन्ने कुरा मेरो आजसम्मको अनुभवले बताएको छ किनभने तिमी पितृसत्तात्मक समाजका लोग्नेमान्छे हौं, तिम्रा प्रत्येक आचारणलाई समाजले मान्यता 
दिएको छ। तिम्रो जातलाई भार्या चाहिन्छ, सहधर्मिणी होइन। तिमीहरूका अगाडि सम्पर्ण आफ र आफनोपनलाई बिर्सिदिन सक्ने आश्रिता चाहिन्छ। हामी बिउँकिएको तिमीहरूलाई मन पर्दैन। तिमीहरू त मुर्दालाई अँगालेर बाँच्न चाहन्छौं। तिमीहरूको तालमा नाच्ने कठपुतली चाहन्छौ। सत्य कुरा सहन कठिनै हुन्छ (पृ.५)।

वास्तवमा पित्सत्तात्मक सोच भएका अमृतजस्ता पात्रले पत्नीको सहअस्तित्वलाई कदापि सहर्ष स्वीकार गर्न सक्तैनन् । यहाँ बिन्दुले अमृतको पुरुषवादी सोचको विरोध मात्र गरेकी छैनन् अपितु विद्रोहात्मक जवाफ पनि दिएकी छिन् । उनले मसानकी युवतीलेकैं नारीको अस्तित्व र सोचको कदर नहुने घरलाई मसान मान्दै पतिको गृहत्याग गरेकी छिन्। नारीले पतिको गृहत्यागको निर्णय गर्नु भनेको चानचुने कुरा पक्कै होइन। यसलाई विद्रोहको चरम अवस्थाको रूपमा लिइन्छ। नभन्दै बिन्दुले गृहत्याग गरेपछि अमृतले आफू बस्ने कोठामा मसानको नीरवता महसुस गरेका छन् । त्यसैले उनी भन्छन् : "कोठामा एक्लै बसिराख्दा मसानको कहालीलागदो नीरवताले मलाई सलक्क निलिराखेको थियो" (पृ. २) । पत्नी बिन्दुले छोडेर गएपछि आफ़नो पितृसत्तात्मक सोचप्रति अमृतमा पश्चात्तापको भाव देखिन्छ । उनी भन्छन् : "हातमा छउन्जेल मणि हो भनेर चिन्न सकेनौं। जब हातबाट करेर बेपत्ता भयो, अनि हामीलाई बल्ल मणि पो रहेछ भन्ने कुरा थाहा भो" (प. १०)। आफ़नी पत्नीको मनोभावलाई समयमै बक्के कोसिस नगर्दा यहाँ अमृतले सदाका लागि पत्नीसंगको विछोडको पिडा सहनुपरेको छ। यसमा नारीको इच्छा र मनोभावलाई नपुज्ने घर अन्त्वोत्वगत्व मसानघाटमा परिणत हुन्छ भन्ने यथार्थको उद्घाटन गरिएको छ। यहाँ नारीले घरपरिवारका लागि जुनसुकै अवस्थामा जस्तोसुकै सम्कौता सधैं गई्छन् भन्ने पुरुषवादी मनस्थितिका लागि बिन्दुको निर्णय एउटा चोटिलो जवाफका रूपमा प्रस्तुत भएको छ।

सुधा त्रिपाठीको यसै एकाड़ी संग्रहमा संगृहीत पहाडलाई के सजाय दिन्छौं ? भन्ने एकाड़ीमा आफ्नो आत्मसम्मानको रक्षाका लागि शोभाले हत्यासमेत गरेको अवस्था चित्रित भएको छ। यहाँ शोभा एक शिक्षित र आत्मस्वाभिमान पात्रका रूपमा देखिन्छिन् । उनको नजरमा आत्मसम्मान सबैभन्दा महत्वपूर्ण कुरा हो। त्यसैकारण उनी "कुनै पनि नारीको नारीत्वमाथि तुषारपात गर्नु चानचुने अपराध होइन। यसको सजाय तिनले भोग्नैपई" (पृ.३९) भन्छिन् । क्षतविक्षत आत्मसम्मानले त्यस्ता अपराधीलाई सजाय दिन आत्मबल दिएको कुरा स्वीकार्दे उनी भन्छिन् :

ममाथि कलड़ लगाए। मेरो नारीत्वको अपमान गरे। समाजले उनीहरूका कुरामा ताली पिट्यो। मलाई त्यो सह्य हुन सकेन। मभित्रको ताडित नारीत्वले मलाई घचघच्यायो। मभित्रको क्षतविक्षत आत्मसम्मानले त्यस्तो कार्य गर्न मलाई प्रोत्साहित गर्यो, मेरो आत्मबल बढायो (पृ. ४प) ।

शोभा आफले पाँचजनाको हत्या गरेको करा बारम्बार स्वीकार्छिन् र सजायका लागि तयार रहेका बताउँछिन् । उनको नजरमा आत्मसम्मानलाई थिलथिलो बनाउनु सबैभन्दा ठूलो सजाय हो, जुन समाजले गरिसकेको थियो। त्यसैकारण अब दिने अन्य जस्तोसक सजाय आफ़नो लागि सामान्य नै हुने बताउँछिन् । उनी नारीका लागि जेलभित्र र बाहिर एउटै वातावरण देख्छिन् । जेलबाहिर पनि नारीले समाजले बनाएका अनैकौ घेरामा बस्तुपर्ने नियतिलाई उनले यसरी व्यक्त गरेकी छिन् :

खोइ, म त जेलबाहिर र भित्र बराबरै देख्छु । आखिर जेलबाहिर पो कुन उन्मुक्त वातावारणमा बाँचेकी थिएँ र ? मेरो मुटु उकुसमुकुस भएर सधैं छटपटाउँथ्यो । सामाजिक अन्धविश्वासको चौघेराको जेलभित्र धर्मका नेल र हथकडी लगाएर हामी नारीलाई सधैं थुकिएकै त छ, नि ! जेलबाहिर रहँदा मात्रै हाम्रो स्वतन्त्र अस्तित्वको कदर 
कहाँ भएको थियो र ? रातबिरात मारेर मिल्काइएका दिदीबहिनीका लाशले यही कराको साक्षी बकेका छैनन् र ? हामी महिलाहरूको दुर्गति हुँदा, चहर्याइरहेको मुटुको चोट अप्न नसकी चीत्कार गर्दा खोइ कहिल्यै तिमी लोग्नेमान्छेभित्रको मान्छेले यसको वास्ता लियौं (पृ. ४७-४६) ?

शोभाले आफ़नो नारीत्व र आत्मसम्मानको रक्षाका निम्ति आफ़नै काका, काकी र उनका छोरीहरूको हत्या गई्छिन् । काका त लोग्नेमान्छे तर नारी भएर पनि काकीले नारीत्वको सम्मानमाथि तुषारपात गर्नुलाई शोभाले ठूलो अपराधका रूपमा लिएकी छिन्। यसरी तिनीहरूले तयार पारेको पहाडभित्रको ज्वालामुखीको लाभामा स्वयम् तिनीहरू र तिनका छोरीहरू परे। यसमा शोभालाई आफूले गरेको हत्याप्रति रतिभर पनि पश्चात्ताप छैन। उनी भन्छिन् : "मैले यो अपराध परेर होइन बरू गरेर स्वीकारिरहेकी छु। यसैले मलाई हर्ष लागेको छ र साथै गौरव पनि मलाई आफूले नकाम गरेको जस्तो ठ्याम्मै लागेको छैन" (पृ. ४४) उनको दृष्टिमा यो कदम आत्मसम्मानको रक्षाको निम्ति अनिवार्य थियो। यसरी प्रस्तुत एकाड़ीमा नारीले आफ़नो आत्मसम्मानको रक्षाका लागि जस्तोसुकै कदम पनि चाल्नसक्ने अवस्था देखाइएको छ।

\section{निष्कर्ष}

२००६ सालपछि नेपाली नाट्यक्षेत्रमा प्रगतिवादी नाट्यरचना भएका देखिन्छन् भने पचासको दशकपछि प्रकाशित नेपाली नारी नाटक प्रगतिवादका दृष्टिले सशक्त देखिन्छन्। सावित्री पोखरेलको कलंकी समाज (२०४०) नाटकमा नेपाली सामाजको यथार्थ चित्रण गर्दे त्यहाँ विद्यमान कुपरम्परा, कुप्रथा, अन्धविश्वास, जातीय छुवाछुत आदिको विरोध जीवन पात्रका माध्यमबाट गरिएको छ। शारदा सिलवालको माटोको इज्जत (२०४३) नाटकमा नेपाली समाजमा विद्यमान वर्गीय उन्मुक्तिका लागि धनीवर्गले आफ्नो तडकभडकयुक्त जीवनशैलीमा परिवर्तन ल्याउनुपर्ने तथ्यमाथि प्रकाश पारिएको छ। यसैगरी सुधा त्रिपाठीको निःश्वासका गुजुल्टाहरू (२०५y ) एकाड़ी संग्रहमा समावेश उनी फर्कदिनन् कि ! शीर्षकको एकाड़ीमा नारीलाई केवल भोगविलासको साधन ठान्ने पुरुषवादी सामन्ती मानसिकताको भएको अमृतको जीवनमा बिन्दु कहिल्यै फर्कदिनन् भन्ने कुरा देखाइएको छ भने पहाडलाई के सजाय दिन्छों ? भन्ने एकाड़ीमा नारीत्व र आत्मसम्मानको रक्षाका लागि शोभा हत्यारासमेत बनेको अवस्था प्रस्तुत गरिएको छ। वेदकुमारी न्यौपानेको विचलित वर्तमान (२०४६) मा आर्थिक आधारमा विद्यमान अन्तरविरोधको प्रतिबिम्बनलाई उतार्दै सामन्ती व्यवहारको विद्रोहात्मक प्रस्तुतीकरण गरिएको पाइन्छ।

नेपाली नारी नाटकमा नेपाली समाजमा विद्यमान वर्गीय विभेद, लैड्रिक विभेद, छुवाछुत, जातीय विभेद, पितृसत्तात्मक सोच आदिको यथार्थको विद्रोहात्मक चित्रण पाइनुका साथै जीवन, विश्वनाथ, शोभा, वसन्तजस्ता प्रगतिवादी-कान्तिकारी पात्रको परिकल्पनाद्वारा समतामूलक समाज स्थापनाको तत्परतालाई पनि देखाइएको छ।

\section{सन्दर्भ सामग्रीसूची}

अधिकारी, धर्मराज. (२०६९). "प्रगतिवादी नेपाली साहित्यको परम्परा". भृकुटी. काठमाडौं : भृकुटी एकेडेमिक पब्लिकेसन्स. (१०). पृ. २०६-२२०।

न्यौपाने, वेदकुमारी. (२०४६). विचलित वर्तमान. काठमाडौँ : देवानन्द न्यौपाने । 
पोखरेल, गुरूप्रसाद. (२०६९). 'परिचयात्मक सन्दर्भमा प्रगतिवाद'. भृकुटी. काठमाडौं : भृकुटी एकेडेमिक पब्लिकेसन्स. (१०). पृ. ७९-५प ।

पोखरेल, सावित्री. (२०४०). कलंकी समाज. (दो.सं.). ललितपुर : उन्नयन प्रकाशन ।

पौडेल, गोपीन्द्र. (२०६९). 'सामाजिक रूपान्तरणमा मार्क्सवादी साहित्यको भूमिका'. भृकुटी. काठमाडौं : भृकुटी एकेडेमिक पब्लिकेसन्स. (१०). पृ. द६-९९।

प्रधान, कृष्णचन्द्र. (२००६). भन्ज्याङनिरै. काठमाडौं : कृष्णचन्द्रसिंह प्रधान ।

भट्ट, आनन्ददेव. (२०६९). 'प्रगतिवादी साहित्य : आवश्यकता र महत्व'. भृकुटी. काठमाडौं : भृकुटी एकेडेमिक पब्लिकेसन्स. (9०). प्. पू०-प६६।

राया, राधिका. (२०४९). जीवनको इच्छा. भापा : जुही प्रकाशन ।

सुवेदी, पुरुषोत्तम. (२०६९). 'नेपालमा प्रगतिशील साहित्यिक आन्दोलनको पृष्ठभूमि'. भृकुटी. काठमाडौं : भृकुटी एकेडेमिक पब्लिकेसन्स. (१०). पृ. २४Y-२Y७।

सिलवाल, शारदा. (२०४३). माटोको इज्जत. काठमाडौं : प्रेम सिलवाल ।

त्रिपाठी, सुधा. (२०४५). नि:श्वासका गुजुल्टाहरू. काठमाडौं : नेपाल राजकीय प्रज्ञा-प्रतिष्ठान । 